\title{
Large carnivore attacks on hominins during the Pleistocene: a forensic approach with a Neanderthal example
}

\author{
Edgard Camarós ${ }^{1,2}$ • Marián Cueto ${ }^{3}$ - Carlos Lorenzo ${ }^{1,2}$. \\ Valentín Villaverde $^{4}$ • Florent Rivals ${ }^{1,2,5}$
}

Received: 7 November 2014 / Accepted: 6 May 2015

(C) Springer-Verlag Berlin Heidelberg 2015

\begin{abstract}
Interaction between hominins and carnivores has been common and constant through human evolution and generated mutual pressures similar to those present in worldwide modern human-carnivore conflicts. This current interaction is sometimes violent and can be reflected in permanent skeletal pathologies and other bone modifications. In the present paper, we carry out a survey of 124 forensic cases of dangerous human-carnivore encounters. The objective is to infer direct hominin-carnivore confrontation during the Pleistocene, which is important to understand behavioral changes during human evolution. In addition, the case of Neanderthals is analyzed in order to find evidence of past attacks using forensic observations. The results obtained pose that Neanderthals could potentially have been involved in dangerous encounters during the Pleistocene, validating our
\end{abstract}

Electronic supplementary material The online version of this article (doi:10.1007/s12520-015-0248-1) contains supplementary material, which is available to authorized users.

Edgard Camarós

ecamaros@iphes.cat

1 IPHES, Institut Català de Paleoecologia Humana i Evolució Social, C/Marcel.lí Domingo s/n, Campus Sescelades URV (Edifici W), 43007 Tarragona, Spain

2 Àrea de Prehistòria, Universitat Rovira i Virgili (URV), Avda. de Catalunya, 35, 43002 Tarragona, Spain

3 Departament de Prehistòria, Universitat Autònoma de Barcelona (UAB), Campus UAB, Edifici B, 08193 Barcelona, Spain

4 Departament de Prehistòria i Arqueologia, Universitat de València, Avda. Blasco Ibáñez, 28, 46010 València, Spain

5 ICREA (Institució Catalana de Recerca i Estudis Avançats), Barcelona, Spain methodology to approach past attacks from a forensic perspective.

Keywords Carnivores · Interaction · Confrontation · Forensic medicine $\cdot$ Neanderthals

\section{Introduction}

Predation is assumed to be a fundamental influence in the evolution of primate behavior (Cheney and Wrangham 1987). Consequently, deterrence of predation has been described as an element with a high sociobiological impact on the origin of the human condition (Fay et al. 1995). Brain (1981) once asked "Who killed the Australopithecines?" as he recognized that the interaction between hominins and carnivores had enormous potential for the study of human behavioral changes; he pointed out that humans could effectively handle these interactions simply by increased intelligence and development of technology (Brain 1981).

Research on direct confrontation between hominins and large carnivores is clearly important (Hart and Sussman 2011), and yet this subject has not been extensively explored, largely due to the difficulty of approaching the topic using only archaeology and/or paleoanthropology. Nevertheless, dangerous encounters between carnivores and archaic forms of genus Homo have been inferred (e.g., Brain 1981; Bunn and Ezzo 1993; Treves and Naughton-Treves 1999; Boaz et al. 2004; Baquedano et al. 2012). The interactions between hominins and large carnivores have occurred at high frequency and taken different forms that generated mutual pressures (Rosell et al. 2012). Scenarios emerging from these pressures include dependency (scavenging) (Binford 1989; Stiner 1994), confrontation (carnivore 
hunting) (Auguste 1995; Arribas et al. 1997; Tillet 2002; Pérez Ripoll et al. 2010), competition for the use of caves as dwellings (Blasco and Rosell 2009), and the exploitation of common prey (Pettitt 1997). One of the latest documented scenarios is domestication during the Late Pleistocene (Germonpré et al. 2013).

Today, similar pressures result globally in conflicts between different wild large carnivore species and humans (Treves and Karanth 2003; Pettigrew et al. 2012). For example, conflicts are mainly related with snow leopards (Uncia uncia), leopards (Panthera pardus), tigers (Panthera tigris), and Asian black bears (Ursus thibetanus) in Asia (e.g., Hussain 2003; Mishra 1997; Sekhar 1998; Dhar et al. 2008); lions (Panthera leo), African hunting dog (Lycaon pictus), and hyenas (Crocuta crocuta) in Africa (e.g., Patterson et al. 2004; Gusset et al. 2009; Kolowski and Holekamp 2006); wolves (Canis lupus), cougars (Puma concolor), and bears (Ursus arctos horribilis, Ursus americanus) in North America (e.g., Musiani et al. 2003; Conrad 1992; Herrero and Fleck 1990); jaguars (Panthera onca) and pumas (Puma concolor) in South America (e.g., Polisar et al. 2003; Mazzolli et al. 2002); dingoes (Canis lupus dingo) in Australia (e.g., Allen and Sparkes 2001); or brown bears (Ursus arctos) and wolves (Canis lupus) in Europe (e.g., Swenson et al. 1999; Linnell et al. 2002). The reasons for these conflicts are mainly associated with the similar resource use patterns of people and wild animals (Ahmed et al. 2012) and with their overlapping habitats (Agarwal and Mumtaz 2009). These conflicts have generated a rising incidence of attacks that constitute an increasingly serious form of human-wildlife confrontation conflict (e.g., Herrero and Higgins 2003; Conover 2008; Brown and Conover 2008; Neto et al. 2011), related to shrinking wild carnivore habitats (Skuja 2002), loss of their prey (Thakur et al. 2007), or wildlife hunting (Inskip and Zimmermann 2009). As such, they present a scenario of mutual pressures between humans and wildlife that may be comparable to the relationships that existed between large carnivores and hominins during the Pleistocene. Fossil humans could have been involved in direct confrontation scenarios (dangerous encounters) with large carnivores similar to those seen today, which then have the potential to provide insight into hominin behavior and even inferences regarding social organization (e.g., Dhar et al. 2008; Nabi et al. 2009a, b; Rasool et al. 2010).

For this reason, we carried out a forensic survey with the objective of developing a comparative methodology aimed at identifying direct confrontations between hominins and carnivores during the Pleistocene. An application example is provided for the case of Neanderthals as a proof of concept, as these hominins are assumed to be a human form that had a close relationship with large carnivores (e.g., Estévez 2004; Dusseldorp 2011).

\section{Materials and methods}

Forensic information of carnivore attacks on humans was obtained by carrying out an intensive bibliographic survey. The data selected were obtained in specialized medical journals involving forensic cases where victims and injuries caused by carnivores could be clearly documented. The carnivores selected were members of the ursid, felid, and canid families. Although few well-described forensic cases exist for hyenids, this carnivore is also included in our survey (except for statistical observations).

All information has been transferred to a database where individual characteristics of either the victims or the attacking carnivores can be examined. Each case has been individualized so specific aspects of the resulting injuries inflicted by the animals could be overviewed. All injuries (including bone damage and general body wounds) are clustered depending on their location in skeletal and body zones (Fig. 1). A total of 124 cases are studied, and of these, 92 are considered for the quantitative analysis as the damage can be isolated. All information related to each case is available as Online Resource Material (the forensic cases database is also related to the bibliographic list provided) (Online source 1 and 2).

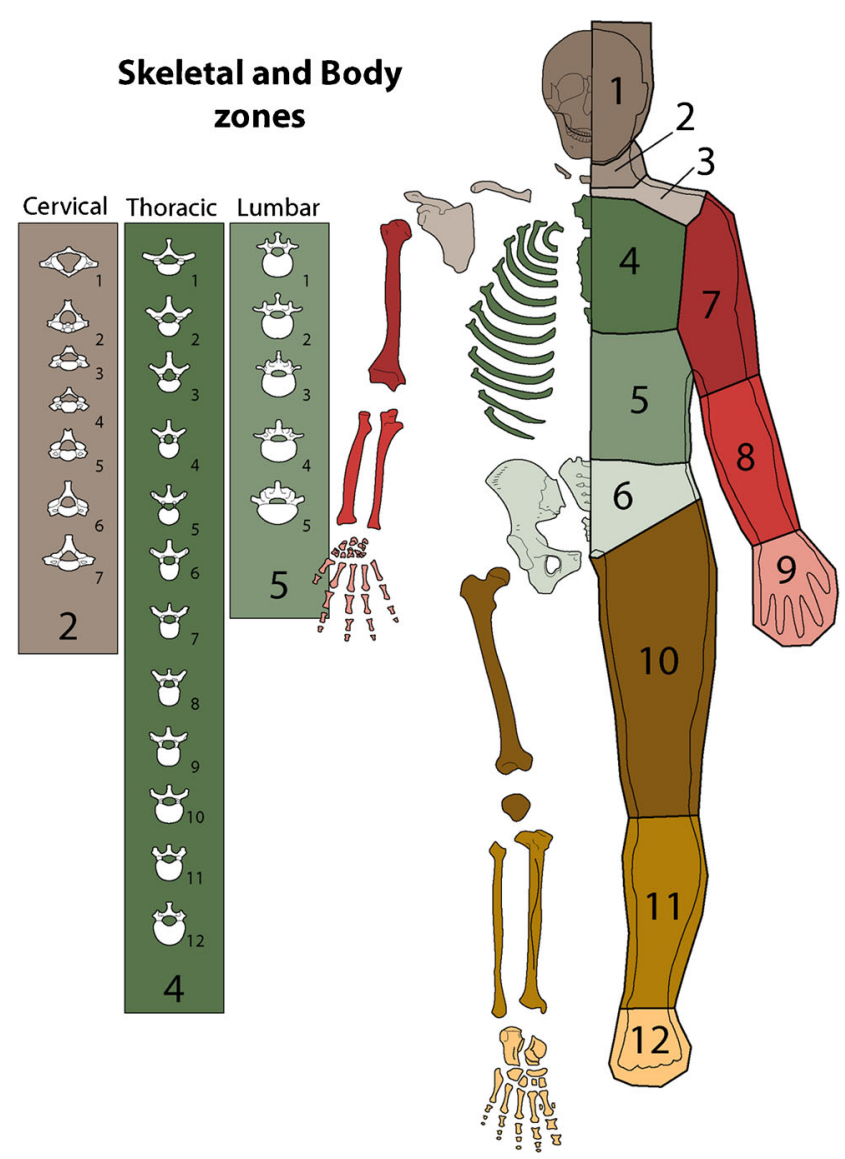

Fig. 1 Classification of skeletal and body zones used in the forensic survey 
Observations are applied to the study of a Neanderthal bone fragment from the site of Cova Negra and to the register of traumatic lesions observable on the Neanderthal skeletons provided by Berger and Trinkaus (1995).

Forensic information is evaluated and patterns for each carnivore family in direct confrontation with humans are presented. A statistical approach is developed with the objective of observing major and minor injuries inflicted by each carnivore family. Nevertheless, our main interest is documentation of bone damage caused by all carnivores.

\section{Results and discussion}

\section{Forensic survey of carnivore attacks to humans}

Interaction between humans and wild animals has increased in recent decades (Ambarli and Bilgin 2008; Inskip and Zimmermann 2009), with a high proportion of these contacts being violent (Dhar et al. 2008). Carnivore attacks are characterized by the combined occurrence of injuries (including puncture wounds, lacerations, avulsions, and bone fractures (Baliga et al. 2012)), crushing, and penetrating trauma (Agarwal et al. 2011). Humans attacked by large carnivores are consequently at risk of suffering blunt and penetrating trauma caused by teeth, paws, and claws, which may lead to a local infection (Capitini et al. 2002; Kunimoto et al. 2004; Lehtinen et al. 2005; Türkmen et al. 2012) because wounds are often contaminated with a variety of pathogens (polymicrobial infection) such as Pasturella multocida and others (Kizer 1989; Isotalo et al. 2000; Linnell et al. 2002; Abrahamian and Goldstein 2011). Fatal attacks are common, especially in Africa and Asia (Conrad 1992), although many cases are reported in which victims survive a violent encounter with a carnivore (Agarwal et al. 2011). After a carnivore attack, victims may develop future specific pathologies such as arthritis (e.g., Burdge et al. 1985) or others (see Papadopoulos et al. 1999).

Although these are general trends observed in carnivore attacks, specific patterns can be identified in the forensic survey resulting from different carnivore families.

\section{Ursidae}

Direct confrontation between humans and bears is relatively common in different parts of the world (Lathrop 2007) and must be considered as either predatory or defensive (Herrero 1985; Herrero and Fleck 1990). Subspecies involved in these dangerous encounters are the black bear (Ursus americanus) (Murad and Boddy 1987), grizzly bear (Ursus arctos horribilis) (Cardall and Rosen 2003; Kunimoto et al. 2004), Asian black bear (Ursus thibetanus) (Agarwal et al. 2011), and less commonly the polar bear (Ursus maritimus)
(Herrero and Fleck 1990) and brown bear (Ursus arctos) (Ambarli and Bilgin 2008). Although other subspecies are involved in attacks on humans (Rajpurohit and Krausman 2000; French 2001), only those cited here were studied in our forensic research. A total of 45 cases were analyzed.

In general, death is not common after a bear attack (Herrero and Fleck 1990), although serious injuries are generated by teeth, claws, and paws (French 2001). The bear attack pattern is one of the best studied in forensic medicine (e.g., Rasool et al. 2010). Bears tend to rear up on their hind legs and strike victims with their claws (Dhar et al. 2008). Biting the victim is also common, and a bear attack ends with different degrees of minor and major injuries, predominantly located in the upper half of the body (Dhar et al. 2008; Rasool et al. 2010; Agarwal et al. 2011; Baliga et al. 2012), especially in the head and face (Thakur et al. 2007).

The present observation of a total of 45 forensic cases is commensurate with this known attack pattern of bears. Figure 2a shows that within the 38 case studies with bone modifications, the main bone damage is located in the head zone (skull and mandible) and upper limbs (clavicle, humerus, radius, ulna, metacarpals, and hand phalanges). Bears tend to attack the victim's head, causing wounds and fractures in that zone, and humans react by protecting themselves with their arms, causing damage in that region. Long-bone diaphyseal linear, comminuted, and segmental fractures in the upper limb are not rare, and finger amputation is also common (Dhar et al. 2008). All these bony injuries are frequently associated with general soft-tissue wounds (Fig. 2b), as observed in other cases (Rasool et al. 2010). Therefore, bone modification after a bear attack would appear to occur in the body areas where other general non-bony wounds are inflicted by the animal.

\section{Felidae}

Feline attacks on humans reflect a predatory behavior in nearly all cases and follow the same pattern employed for predation on other large mammals (Cohle et al. 1990) in both wild and captive contexts (e.g., Hejna 2010). These encounters may not always be fatal for humans (Wright 1991), but due to large cats' attack pattern, they can result in very serious wounds caused by teeth and claws. Feline-human conflicts that end in dangerous encounters are increasingly common occurrences in different parts of the world (Nyhus and Tilson 2004; Inskip and Zimmermann 2009).

The felines (basically leopards (Panthera pardus) (Nabi et al. 2009a), jaguars (Panthera onca) (Neto et al. 2011), lions (Panthera leo) (Packer et al. 2005), tigers (Panthera tigris) (Langley and Hunter 2001), and cougars (Puma concolor)) attack humans in the same way in most cases. They carry out a solitary surprise attack motivated by a predatory behavior that can be stimulated by the quick erratic movements of the victim (e.g., jogging or running) (Conrad 1992; Rollins 
Fig. 2 Different patterns observed in carnivore attacks on humans by Ursidae, Felidae, and Canidae. a Bone damage (fractures/scores/punctures) observed in different cases for each skeletal element; b bone damage (fractures/scores/ punctures) (red line) compared to general wounds (blue dashed line) in different cases for each body zone (numbers refer to Fig. 1); $\mathbf{c}$ average of bone damage compared to general wounds present in all cases. Source data provided as Online Resource Material (see Online Resource 1 and 2)
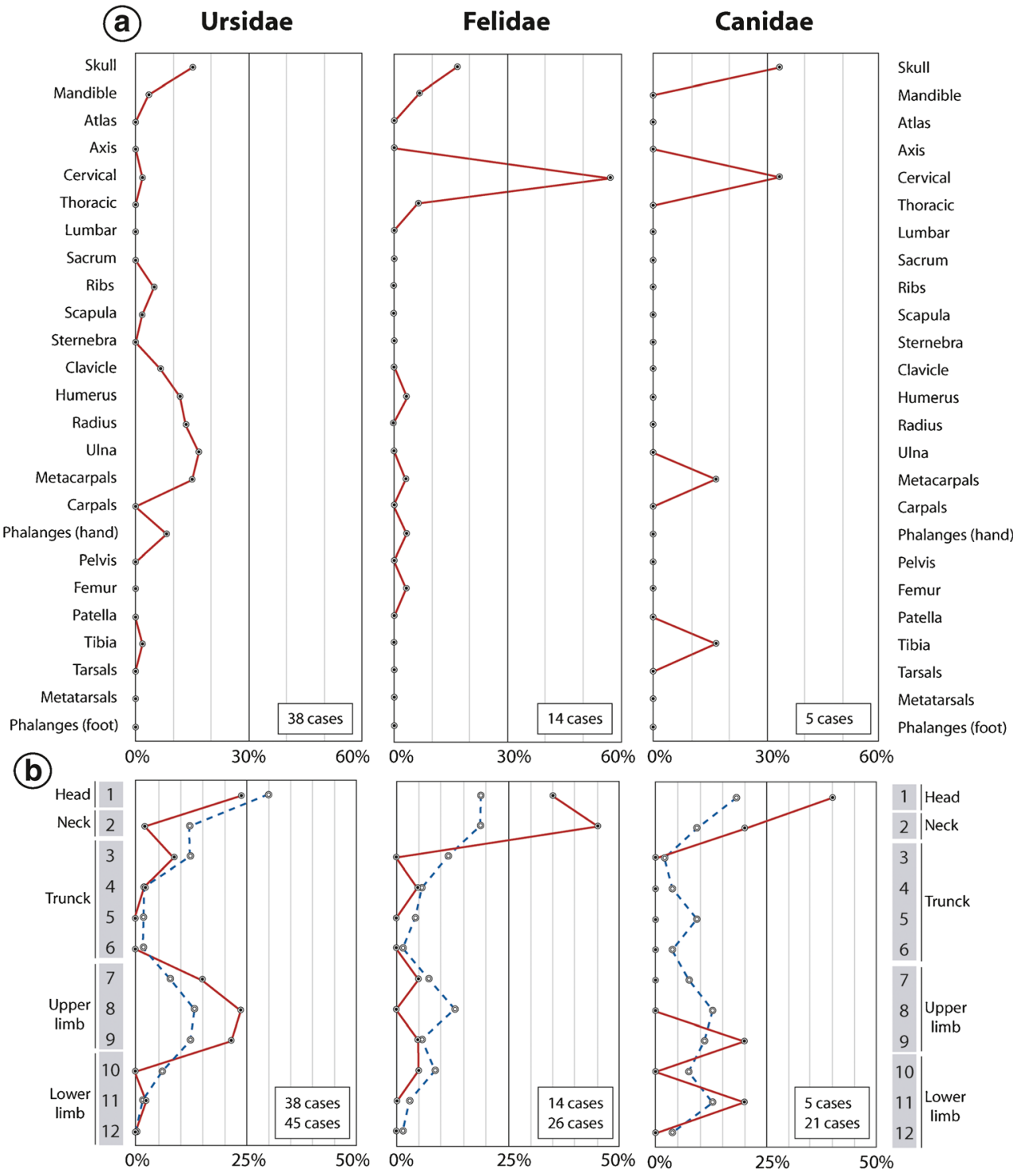

(c)
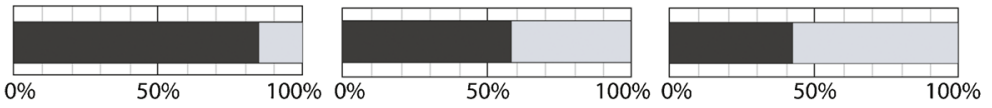

and Spencer 1995). Prey size is considered by felines in their solitary hunting (Atwood et al. 2007); thus, children are commonly attacked (Chum and Pui 2011). Felines rarely employ a head-on attack but prefer to approach the victim from behind or over the shoulder (Chapenoire et al. 2001). This results in major injuries in the head, nape, and neck regions, especially from penetrating bites that cause skull damage, cervical vertebral fractures, and/or damage to the anterior neck structure (Conrad 1992; Hejna 2010; Emami et al. 2012). Claws usually cause deep lacerations in the back. Other body regions, although represented by a minimum number of cases, can also be damaged (e.g., Burdge et al. 1985).

Bone damage on humans is basically defined by the feline's particular attack pattern. The predatory attack involves shaking the prey by the neck region (Bury et al. 2012), causing subsequent cervical lesions (Bock et al. 2000; Murphy et al. 2007; Nabi et al. 2009b; Chum and Pui 2011). This is usually defined by compound fractures of the cervical bodies (Chapenoire et al. 2001). Nevertheless, skull surface damage can also be caused by a big cat attack, and modifications such as scores, punctures, perforations, or cortical fractures caused by several bites may occur (Conrad 1992; Neto et al. 2011).

Our observations of 26 cases ( 14 with bone damage) corroborate previous studies, as bone damage is located in the head and neck area (Fig. 2a). Cervical vertebrae are the principal bone elements that suffer modification after a feline attack on a human. Other skeletal elements can also be affected, resulting from a defensive reaction by the person being attacked. Extremities are not the primary region where felines attack, but limbs are involved in rare cases (Conrad 1992) and 
exhibit comminuted bone fractures (Prayson et al. 2008) (Fig. 2).

Comparison of bone damage with other wounds not related with osteological modification by body zone (Fig. 2) shows good association in 26 cases. However, the upper limbs show more general wounds that do not include bone damage (specifically on the forearm). Wounds are located in this zone because the victims try to defend themselves from the attack with their arms.

\section{Canidae}

Currently, canids (essentially foxes, dingoes, wolves, and domestic dogs) account most frequently for cases of animalrelated fatalities, with a very high number of attacks on humans (see Langley 2005). Our interest in canid-related fatalities was restricted to canid pack attacks and to single wild wolf attacks. Due to their ethology, most canids develop group hunting (Borchelt et al. 1983), and therefore, a single animal attack is somewhat rare in nature with wild specimens, although it happens (Linnell et al. 2002). In the present time, attacks by single canids on humans are rather more common (Weiss et al. 1998; Macbean et al. 2007) but are represented by Canis familiaris, and this is related to domestication and the consequences of living with these animals. Therefore, we have mainly focused on canid pack attacks, a situation where even domestic dogs, as social animals, have an inherent pack instinct that can cause them to become excited to a frenzy by the smell and taste of blood (Kneafsey and Condon 1995). Furthermore, since domestic dog pack attacks are very similar in pattern to those seen with wolf groups in the wild (Butler et al. 2011), they are also included in our survey.

Pack behavior will generate an attack pattern directed toward humans that consists of immobilizing the prey by striking at the limbs. Once the prey has been brought down, canids will attack all parts of the body (Fonseca and Palacios 2013), especially the head and neck area (Kneafsey and Condon 1995; Avis 1999; Linnell et al. 2002; Bury et al. 2012), followed by extremities (Wright 1990). Defensive marks can also appear on the upper and lower extremities (de Munnynck and van de Voorde 2002), and the victim's movements will simultaneously stimulate the attack (Lauridson and Myers 1993), even leading to amputation of portions of a limb (Avis 1999). Biting, clawing, and crushing forces to the head, neck, and hindquarters will produce a combination of wounds, described as punctures, lacerations, and avulsion of skin and soft tissue (Santoro et al. 2011). Bone damage also occurs to those zones (Bury et al. 2012). In the case of wolves, a predominance of injuries on the dorsal aspect of the body has been observed by Nabi et al. (2009a).

As with felines, canids select their prey by size; thus, children are very often targets of attacks (Fouriel and Cartilidge 1995). Because of a child's relatively soft and vulnerable skull, serious penetrating injuries of the cranium have been described (idem.).

A total of 21 cases have been analyzed; five were pack attacks. The canid collective attack strategy leads to the appearance of bone damage on different parts of the body such as the head (skull), the neck (cervical vertebrae), and the arms (metacarpal) and legs (tibia) (Fig. 2a).

Comparison of the body regions where bone damage appears with the location of general wounds (Fig. 2b) after a canid attack indicates that soft tissue injuries are not highly related with osteological modification. In this sense, a canid attack can generate serious wounds all over the body, especially in the trunk region (Nabi et al. 2009a), but this does not mean that bone damage is associated.

\section{Hyenidae}

Hyena attacks are not well reflected in forensic literature and thus are not included in the database and quantitative study of carnivore attack patterns. Nevertheless, this section has been added to illustrate that hyena attacks on humans are common today, just as they could have been in the past.

In Africa, hyenas coexist with humans at a high density in some countries (Yirga et al. 2012), and this situation may lead to dangerous encounters. In situations of hunger, hyenas can attack humans, perceiving small children and the elderly as vulnerable and easier prey (Brain 1981; Gade 2006). Nevertheless, although predatory attacks on people occur, hyenas much more commonly feed on humans by scavenging human tombs in cemeteries (Horwitz and Smith 1988; Yirga et al. 2012).

The scarcity of forensic literature on hyena attacks complicates any inference regarding an attack pattern toward humans. In spite of this situation, Mitchell et al. (2011) have recorded an attack on a 27 -year-old female in Tanzania that reveals a probable pattern. In this case, a single hyena followed a pattern similar to the one employed by large cats, by attacking the head and neck region of the victim in an attempt to cause prey submission, and probably damaging the cervical spine zone (Mitchell et al. 2011). Although hyenas look like canids, genetically they are similar to felines, and in this sense, hyenas probably follow a similar pattern to that of one of the large cats (idem.)

This single case is not sufficient to infer a pattern, especially considering the pattern that hyenas follow to hunt other non-human mammals. Hyenas develop both lone and cooperative prey captures, although individual hunting has a much higher average of success (Watts and Holekamp 2007). The hyena hunting strategy reveals no significant preference for any species, and its behavioral opportunism allows the capture of anything it can overpower (Hayward 2006). Concerning prey size, a single hyena can capture a prey three times its body weight (Watts and Holekamp 2007). 


\section{Comparison between carnivore attacks}

Similarities and differences both exist among carnivore attack patterns on humans. The evidence suggests that carnivores, when attacking humans, follow the same pattern as when hunting non-human prey (Herrero and Fleck 1990), especially if the attack is predatory. In these cases of attacks on humans, prey size again seems to be an important factor (Gade 2006) and is the reason why so many attacks on children have been recorded, especially in cases related with canids, felines, and even hyenas (e.g., Brain 1981; Conrad 1992; Fouriel and Cartilidge 1995; McKee 2003; Gade 2006).

The patterns followed by different carnivores when attacking humans permit the inference that carnivores can be grouped by family, rather than by species, depending on their ethology.

In general, carnivore attacks result in minor or major injuries, and only a relatively small proportion are fatal (Agarwal et al. 2011). However, this depends on the type of carnivore species. In the case of felines, the average number of attacks that lead to death is extremely high when compared to that of bears (Nabi et al. 2009a). This is probably because most cases related to felines are predatory (Neto et al. 2011), in contrast with bear attacks, which may often be related to defensive attacks (of their cubs or their territory) (Ambarli and Bilgin 2008). This is also something that can be inferred in the way a human is attacked. Ursids usually attack their victims from the front and as a dissuasive action (increased by a defensive reaction of the person, understood by the bear as a fighting response) (French 2001). Felines, on the other hand, tend to attack the victim/prey from the rear or over the shoulder (Chapenoire et al. 2001). The case of canids can be also classified as predatory or defensive attacks, and their attack pattern is similar to that of felines in the sense that they target the neck region, shaking the prey into submission (Bury et al. 2012). Nevertheless, the main difference is that canids usually attack in packs and therefore other pack members would help bring down the victim by biting the upper and lower extremities. As in bear attacks, death is not as common in canid attacks as it is following feline attacks.

One common feature of nearly all the carnivore attack cases, whether they are predatory or defensive, is that the victim was alone at the precise moment of the encounter with the attacking animal. Regarding the number of animals attacking, in the wild, felines (except for lion prides) and bears attack alone (although they can be accompanied by their cubs) and canids usually attack in packs.

The behavior of the animal attacking a human will determine the general injury pattern and, because the attack behavior is different for each carnivore family, the injury pattern will differ (Fig. 2). Among all carnivore families studied in the present paper, bears generate much more bone damage in cases of attacks ( $85 \%$ ), followed by felines ( $58 \%$ ), and canids (42\%) (Fig. 2c).

Our observations indicate that each carnivore has a different attack pattern that at the same time generates a different injury pattern, including differences in bone damage. These observations can be a general forensic base for differentiating between different carnivores responsible for an attack on a human, which may be difficult to identify on some occasions (Kiuchi et al. 2008).

\section{Proof of concept: the Neanderthal case}

The present paper has a clear forensic application and interest due to the characterization of the damage caused by carnivore attacks. Nevertheless, the aim of the research was to propose a methodology for collecting evidence for the reconstruction of past attacks. The comparison of a present scenario with a past one is valid because direct confrontation between hominins and carnivores during the Pleistocene, as in the present, involves mutual pressures derived from a conflictive relationship where common interests overlap (e.g., Schuette et al. 2013). Therefore, we use the modern relationship between humans and carnivores as a valid analogy (Treves and Naughton-Treves 1999) in order to approach the study of carnivore attacks on humans.

Providing evidence for this issue is not an easy task, and as a proof of concept, we have selected Neanderthals to validate our methodology. The Neanderthals developed intense interactions with large carnivores (Gamble 1993) due to mutual pressures arising from conflicts where competition was an inherent factor. Many pressures existed between topcarnivore Neanderthals (Bocherens et al. 2001) and carnivores, as both competed directly for resources (e.g., Dusseldorp 2011) and used the same caves (e.g., Straus 1982). The Neanderthals also hunted large carnivores (see Blasco et al. 2010). Moreover, it is not uncommon to find a good representation of carnivore remains in the archaeological sites where Neanderthals are documented, confirming their presence in the same territories (Straus 1992; Mussi 2001; Brugal and Fosse 2004). This scenario provides a context where direct confrontation existed, and therefore, it is an excellent case for applying our forensic observations in order to confirm past carnivore attacks on humans.

The Cova Negra (Spain) site, a well-known cave occupied during the Middle and Upper Pleistocene (Villaverde et al. 1996, 2004), contained 24 Neanderthal bone remains belonging to cranial, dental, and postcranial elements (Arsuaga et al. 2007). We have analyzed one of them (CN42174b), a cranial fragment belonging to the central part of a right parietal (idem.), due to its high similarity with the punctures present at cranial fragment SK-54 from Swartkrans (South Africa) described as a fossil reflecting a leopard attack to an 
Australopithecus by Brain (1981). The parietal fragment bone CN42174b (Fig. 3) presents two measurable punctures on the exocranial surface, produced by a large carnivore (Fig. 3b, c), although the damage was interpreted as the action of a small carnivore by Arsuaga et al. (2007). The length and breadth have been measured and compared with data available from experimental samples provided by Domínguez-Rodrigo and Piqueras (2003) and Delaney-Rivera et al. (2009). The results show how the size of both punctures matches the largest ones visible on Fig. 3a, comparable with bears, large canids, or hyenas.

The punctures have been produced by both canines (left and right) of a carnivore with an intercanine width of $17.74 \mathrm{~mm}$, which would correspond to a medium-sized carnivore, according to Murmann et al. (2006). If we take in account our forensic observations (Fig. 2) and the probable size orientation provided by neotaphonomic studies (Fig. 3a), we can propose that the Cova Negra Neanderthal represented by the CN42174b fragment reflects an attack by a large felid. This is something coherent in relation with the faunal spectrum present at Cova Negra Mousterian levels, where Panthera pardus has been identified (Villaverde et al. 1996). This interpretation is different to the one provided by Arsuaga et al. (2007), where they argued that the carnivore damage was generated postmortem by a fox-size carnivore. This new interpretation is related to our present taphonomic analysis of the fossil specimen.

Nevertheless, application of our forensic observations to the paleoanthropological record is not the only strategy available to verify past carnivore attacks on Neanderthals. Proof can also be obtained by paying attention to the paleopathologies displayed by Neanderthal skeletons.

Berger and Trinkaus (1995) studied traumatic lesions and posttraumatic degenerative changes in a large Neanderthal skeleton assemblage obtained from different archaeological sites. These authors recognized a high incidence of Neanderthal head and neck trauma (Berger and Trinkaus 1995: 845) and considered that anatomical distribution of traumatic lesions could provide an insight into Neanderthal behavioral patterns (Berger and Trinkaus 1995: 841); we would agree with this. They attempted to understand these lesions by comparing trauma among Neanderthals with lesion distributions from different recent human samples. The Neanderthal traumatic lesion pattern appears to be extremely similar to the one presented by North American professional rodeo athletes (Berger and Trinkaus 1995: 848). Berger and Trinkaus's main conclusion was that this general pattern was the result of frequent close encounters between Neanderthals and dangerous
Fig. 3 a Cova Negra puncture sizes compared to the mean percentages of tooth pit sizes on diaphyses produced by different carnivores, according to Domínguez-Rodrigo and Piqueras (2003) (1) and DelaneyRivera et al. (2009) (2); b Cova Negra right parietal $\mathrm{CN} 42174 \mathrm{~b}$ with punctures $A$ and $B$ highlighted and $\mathbf{c}$ detail of the punctures with the interpuncture distance measured
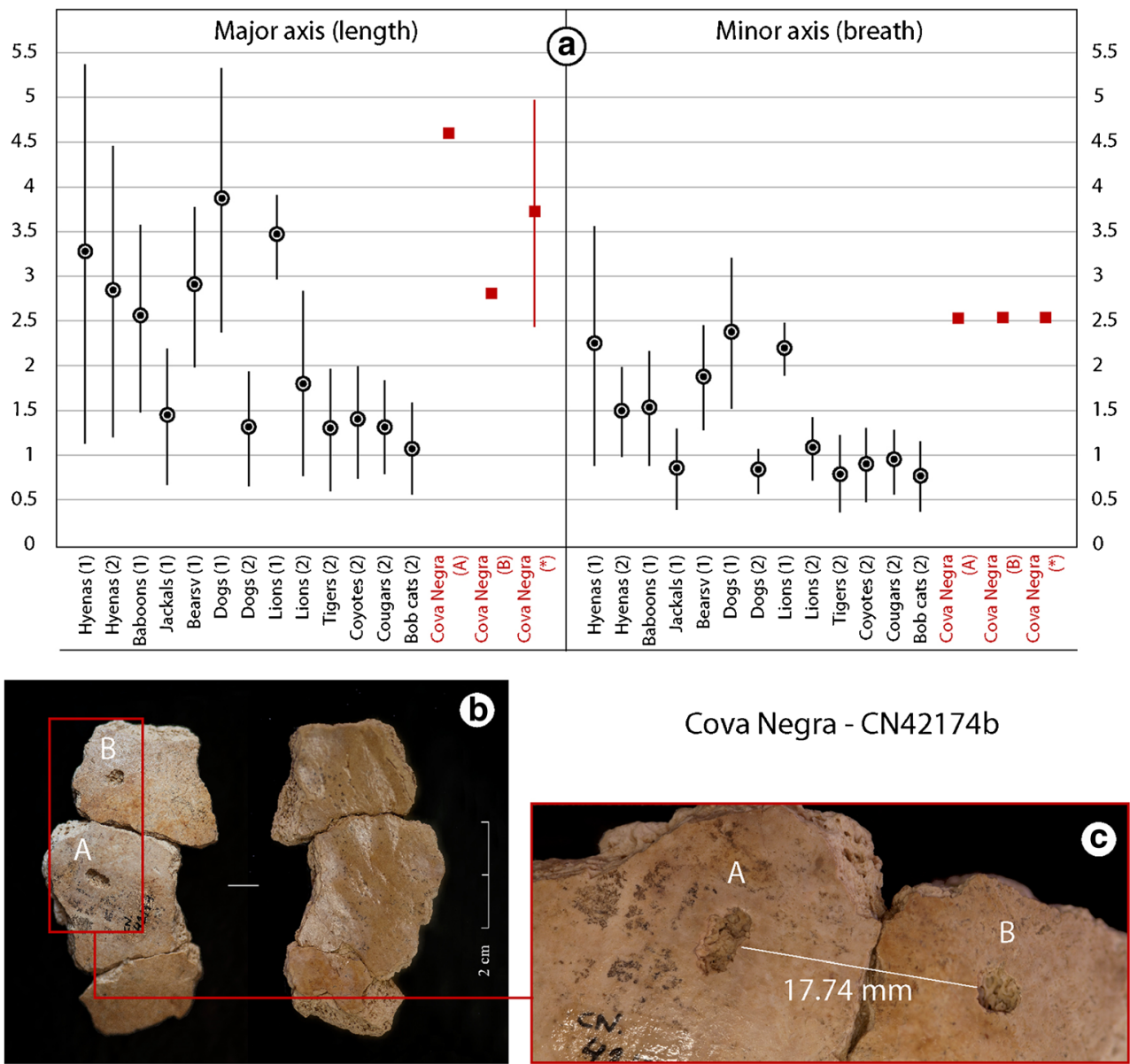

Cova Negra - CN42174b

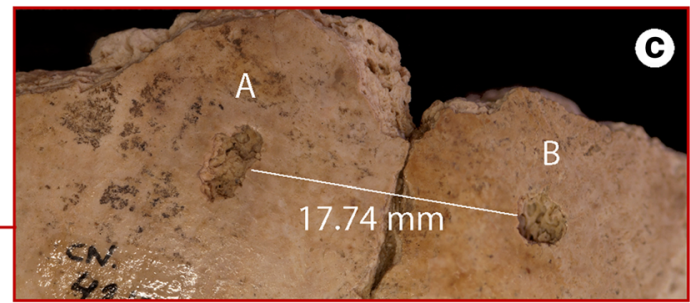


prey, due to their hunting strategy (defined by their available body-to-body technology) (Berger and Trinkaus 1995: 850).

The anatomical distribution pattern of traumatic lesions generated by carnivore attacks on modern humans is plotted in Fig. 4a, together with the one provided by Berger and Trinkaus (1995). A close match is evident between the Neanderthal distribution and attacked humans, providing an alternative explanation to the "rodeo rider" hypothesis and a plausible scenario that could explain Neanderthal trauma.

The similarity of the trauma pattern between Neanderthal and Early Anatomically Modern Humans (EAMH) has led to recent questioning of the rodeo rider analogy (Trinkaus 2012). New alternatives, such as interhuman violence, are now proposed to explain the persistence of a similar traumatic injury pattern in the Upper Paleolithic (Trinkaus 2012: 3693). Results of a foraging mobility can also be an explanation for this common pattern (Trinkaus 2012: 3692), as has already been proposed (Berger and Trinkaus 1995).

The injury pattern of humans attacked by carnivores has also been compared with the anatomical distribution of traumatic injuries in EAMH provided by Trinkaus (2012), and it also showed a close match (Fig. 4b).

In this sense, direct confrontation between Neanderthals and carnivores could represent an alternative and plausible explanation for the injury pattern found on Neanderthal anatomical remains. Dangerous encounters between
Neanderthals and large carnivores would be reflected in their skeletons in the form of fractured bones or injuries derived from posttraumatic degenerative osteological changes, as happens with modern cases (e.g., arthritis; see Burdge et al. 1985).

Furthermore, we can propose direct confrontation as a form of interaction between hominins and carnivores that also affected EAMH during the Upper Paleolithic. This would give an idea of the long duration of conflict between hominins and carnivores during the Pleistocene, which continues even in the present time due to mutual pressures.

The scenario of hominins as carnivore preys appears to be much more common than it was previously thought. Predation among hominins is not just restricted to Neanderthals and EAMH as we have discussed; early ancestors were also attacked (e.g., Brain 1981; Bunn and Ezzo 1993; Boaz et al. 2004; Eppinger et al. 2006; Baquedano et al. 2012; Curnoe and Brink 2010). Therefore, confirming predation on hominins through past attacks, especially in early moments of our evolution, is an essential task to accomplish in order to analyze the development of hominin behavior as it is an influence for cooperation emergence (Hart and Sussman 2011) or technological development (Brain 1981).

The effort to confirm past carnivore attacks is important because it is possible to extract social aspects of this specific relationship. The study of social factors related with modern carnivore attacks on humans can give ideas about behavioral
Fig. 4 Percentage distributions of traumatic lesions by anatomical region caused by carnivores compared to a Neanderthal lesions sample (Berger and Trinkaus 1995) and b Neanderthals and Early Modern Humans (Trinkaus 2012)

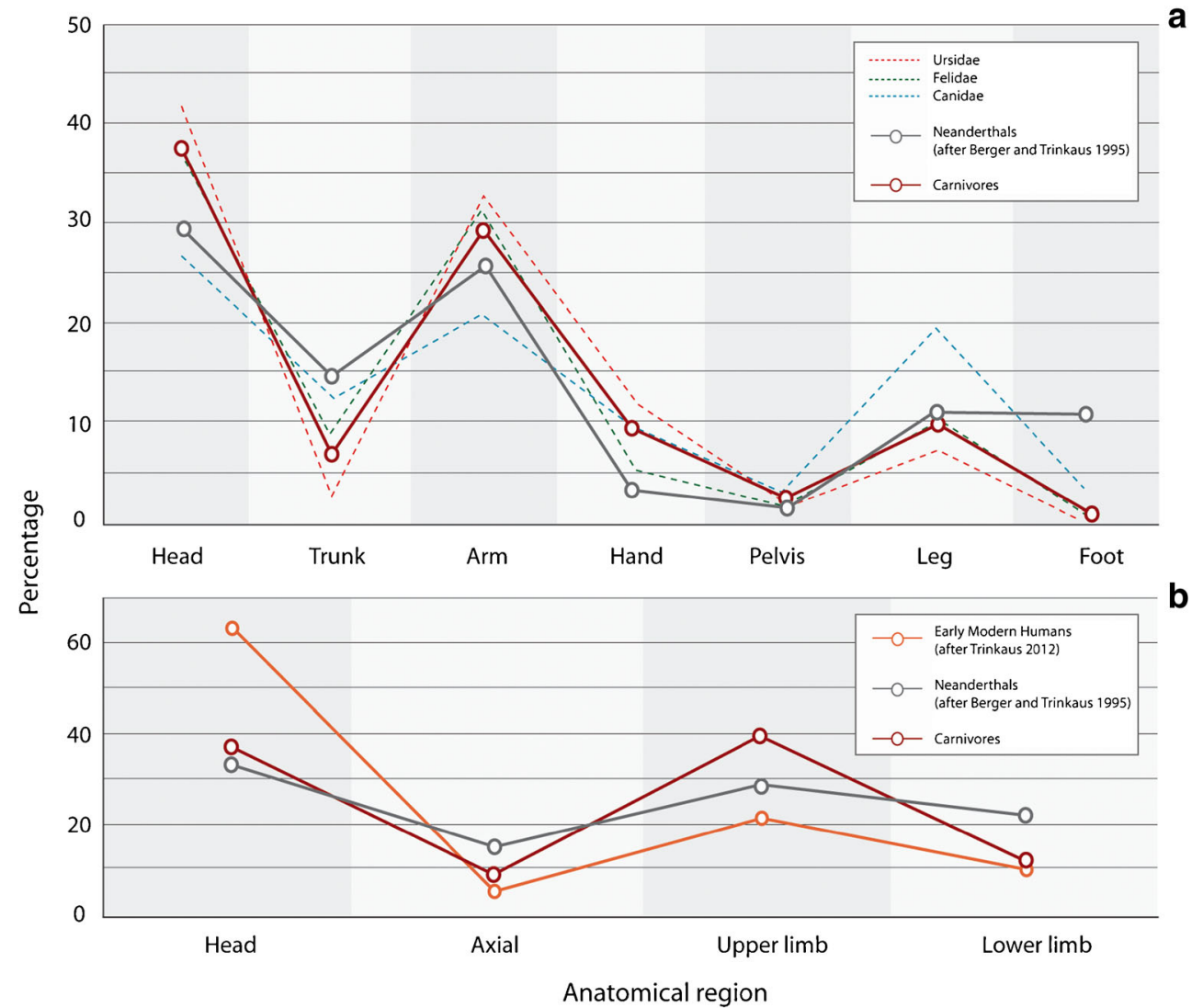


inferences derived from direct confrontation during the Pleistocene. An interesting issue is the fact that, in Tanzania, for example, risk factors are recognized that can result in a lion attack, such as poorly constructed huts, walking long distances to resources, sleeping outdoors at night, or sightings of bush pigs (Kushnira et al. 2010). In India, bear attacks are more related with territoriality, and villagers try to avoid attacks from bears by using a dog for protection and/or carrying weapons (Ambarli and Bilgin 2008). Another technique used in India to avoid bear attacks has been to travel in groups and avoid isolation (Agarwal et al. 2011), as nearly all attacks occurred when a person was alone collecting firewood in the forest (Dhar et al. 2008).

In North America, activities that involve carrying dead ungulates, such as hunting, may attract grizzly bears, and this could end in a dangerous encounter (Herrero and Fleck 1990). Concerning felines like cougars, jogging is an activity that may motivate a predatory attack (e.g., Neto et al. 2011). In the case of wolves, being accompanied by a dog may generate an aggressive behavior by wolves toward the dog (Linnell et al. 2002), although a common recommendation is to be accompanied by a dog to avoid carnivore attacks (see French 2001). In this sense, domesticated canids would provide security, although co-existing with dogs also has a high price due to the large number of domestic attacks recorded (Dhar et al. 2008).

Another significant factor related with social organization issues is the age and gender observed in a very high average of carnivore attacks in Asia. Rasool et al. (2010) report that the bear attack cases they studied $(n=417)$ showed a predominance of middle-aged ( $96.8 \%$ ) male victims $(80.33 \%)$, which is attributed to the outdoor activities undertaken predominantly by men, rather than by women, in Indian society. This was also observed in Sumatra (Indonesia) with tiger attacks, where the typical victim is a middleaged male working in his fields near the forest edge during the day (Nyhus and Tilson 2004). This pattern is also similar in Africa and may reflect a sexual division of labor or sex-differentiated ranging patterns among humans, as has been pointed out by Treves and Naughton-Treves (1999). A gender connection is also apparent in the confrontation between Maasai and lions, where spearing a male lion is part of a manhood ritual that provides immense prestige and a public display of bravery (Hazzah et al. 2009), as well as an inherent risk.

In summary, examples of current direct confrontation between humans and large carnivores can help explain past carnivore attacks on humans and contribute ideas about how to recover human behavior by analyzing this complex relationship (Treves and Naughton-Treves 1999).

\section{Conclusion}

The conflict between humans and large carnivores has been present and constant throughout human evolution, enduring even to modern times. This conflict made direct confrontation during the Pleistocene an inherent factor in the relationship between hominins and carnivores. We provide a forensic methodology that is useful in diagnosing carnivore-related damage on human bones and allows discernment of the type of carnivore responsible for lesions found on fossil hominins based on the anatomical patterning. Therefore, bone damage resulting from a current-day carnivore attack can be used in a positive manner to recover information about past carnivore attacks by comparing it with fossil hominin traumas.

In the present paper, we have applied our forensic observations to Neanderthal traumatic lesions provided by Berger and Trinkaus (1995) as a proof of concept and provide an alternative explanation to the paleopathologies present on the Neanderthal skeletons related to carnivore attacks. Although evidence of attacks on Neanderthals by carnivores has been gleaned by just studying paleoanthropological remains (Cova Negra is one example discussed here), we postulate that comparison of bone damage with current forensic records is also a positive strategy for recovering this information as an actualistic framework to generate new approaches. Furthermore, we have observed that EAMH lesions are also explainable in a context of attacks on humans by large carnivores. In this sense, we prove with our forensic methodology that not just Neanderthals were attacked by carnivores, also EAMH were. This scenario seems to have been common during the Pleistocene and continues today due to similar mutual pressures.

Therefore, predation on hominins appears to be a common scenario during the Pleistocene, and it has to be assumed as a constant influence in human evolution, and much more attention must be paid to this. In this sense, our methodology provides new insight in order to develop new perspectives concerning the role of predation in our evolution.

Understanding the dimensions of the conflict between hominins and carnivores and providing evidence of its consequences, such as carnivore attacks on fossil hominins, is an important issue due to its deep social and cultural implications. If we consider the current relationship between hominids and carnivores as a valid analogy (Treves and Naughton-Treves 1999; Hart and Sussman 2011), we will understand to the necessity of understanding the interaction between hominins and carnivores during the Pleistocene. Confirming past carnivore attacks is an important improvement on the knowledge of this issue, although more research is needed in future to calibrate its sociobiological implications in human evolution. 
Acknowledgments We would like to express our gratitude to R. Vallender (Canadian Wildlife Service), V. Santucci (National Park Service, USA), A. Sanchis, and Museu de Prehistòria de València for their facilities so this paper could be developed. We would also like thank the comments of the anonymous reviewers. This research was carried under an IPHES and IIIPC/UC project supported by the Government of Cantabria and by two research projects founded by Ministerio de Economía y Competitividad (HAR2010-19957/HIST and HAR2013-48784-C3-1-P) and project 2014-SGR-900 (AGAUR). E. Camarós is beneficiary of a FI/ AGAUR (DGR2013) grant of the Catalan Government and a BE/AGAU R Grant (2012 BE 00971) at the Eberhard Karls-UniversitätTübingen. C. Lorenzo works under the research projects funded by Ministeriode Economía y Competitividad (CGL2012-38434-C03-01 and 03) and AGAUR (2014 SGR 899).

\section{References}

Abrahamian FM, Goldstein EJC (2011) Microbiology of animal bite wound infections. Clin Microbiol Rev 24(2):231-246

Agarwal A, Mumtaz I (2009) Human-carnivore conflicts. Injury 40: 1018-1019

Agarwal A, Hirachan S, Shrestha P, Belokar WK (2011) Penile fracture caused by wild bear attack. J Coll Med Sci-Nepal 7(1):47-51

Ahmed RA, Prusty K, Jena J, Dave C, Das SKR, Sahu HK, Rout SD (2012) Prevailing human carnivore conflict in Kanha-Achanakmar Corridor, Central India. World J Zool 7(2):158-164

Allen LR, Sparkes EC (2001) The effect of dingo control on sheep and beef cattle in Queensland. J Appl Ecol 38:76-87

Ambarli H, Bilgin CC (2008) Human-brown bear conflicts in Artvin, northeastern Turkey: encounters, damage, and attitudes. Ursus 19(2):146-153

Arribas A, Díez JC, Jordá FJ (1997) Primeras ocupaciones en los depósitos Pleistocenos de la Cueva de los Torrejones (Sistema Central Español, Tamajón, Guadalajara): litoestratigrafía y actividad biológica. Cuaternario y Geomorfología 11(1-2):55-66

Arsuaga JL, Villaverde V, Quam R, Martínez I, Carretero JM, Lorenzo C, Gracia A (2007) New Neandertal remains from CovaNegra (Valencia, Spain). J Hum Evol 52:31-58

Atwood TC, Gese EM, Kunkel KE (2007) Comparative patterns of predation by cougars and recolonizing wolves in Montana's Madison Range. J Wildl Manag 71(4):1098-1106

Auguste P (1995) Chasse et charognage au Paléolithique Moyen: l'apport du gisement de Biache-Saint-Vaast (Pas-de-Calais). Bull Soc Préhist Fr 92(2):155-167

Avis SP (1999) Dog pack attack: hunting humans. Am J Forensic Med Pathol 20(3):243-246

Baliga SD, Urolagin SB, Balihallimath LJ (2012) Bear attack injury to maxillofacial region: report of 3 cases and review of management. J Oral Maxillofac Surg Med Pathol 24(4):198-203

Baquedano E, Domínguez-Rodrigo M, Musiba C (2012) An experimental study of large mammal bone modification by crocodiles and its bearing on the interpretation of crocodile predation at FLK Zinj and FLK NN3 Original Research Article. J Archaeol Sci 39(6):17281737

Berger TD, Trinkaus E (1995) Patterns of trauma among the neandertals. J Archaeol Sci 22(6):841-852

Binford LR (1989) Étude taphonomique des restes fauniques de la Grotte Vaufrey, Couche VIII. Mém Soc Préhist Fr 19:535-564

Blasco R, Rosell J (2009) Who was the first? An experimental application of carnivore and hominid overlapping marks at the Pleistocene archaeological sites. C R Palevol 8(6):579-592

Blasco R, Rosell J, Arsuaga JL, Bermúdez de Castro JM, Carbonell E (2010) The hunted hunter: the capture of a lion (Pantheraleofossilis) at the Gran Dolina site, Sierra de Atapuerca, Spain. J Archaeol Sci 37(8):2051-2060

Boaz NT, Ciochon RL, Xu Q, Liu J (2004) Mapping and taphonomic analysis of the Homo erectus loci at locality 1 Zhoukoudian, China. J Hum Evol 46(5):519-549

Bocherens H, Toussaint M, Billiou D, Patou-Mathis M, Bonjean D, Otte M, Mariotti A (2001) New isotopic evidence for dietary habits of Neandertals from Belgium. J Hum Evol 40:497-505

Bock H, Ronneberger DL, Betz P (2000) Suicide in a lions' den. Int J Leg Med 114:101-102

Borchelt PL, Lockwood R, Beck AM, Voith VL (1983) Attacks by packs of dogs involving predation on human beings. Public Health Rep 98(1):57-66

Brain CK (1981) The Hunters or the Hunted? An introduction to African cave taphonomy. Univ Chic Press, Chic

Brown DE, Conover MR (2008) How people should respond when encountering a large carnivore: opinions of wildlife professionals. Hum-Wildl Confl 2(2):194-199

Brugal JP, Fosse Ph (2004) Hommes et Carnivores au Paléolithique. Hommage à Philippe MOREL. Rev Paléobiol 23(2):575-595

Bunn HT, Ezzo JA (1993) Hunting and scavenging by Plio-Pleistocene hominins: nutricional constraints, archaeological patterns, and behavioural implications. J Archaeol Sci 20:365-398

Burdge DR, Scheifele D, Speert DP (1985) Serious Pasteurella multocida infections from lion and tiger bites. JAMA 253(22):3296-3297

Bury D, Langlois N, Byard RW (2012) Animal-related fatalities-part I: characteristic aautopsy findings and variable causes of death associated with blunt and sharp trauma. J Forensic Sci 57(2):370-374

Butler LG, Beckmen KB, Dale BW, Farley S (2011) Findings related to the march 2010 fatal wolf attack near Chignik lake, Alaska. ADF\&G, Div Wildl Conserv, Palmer

Capitini CM, Herrero IA, Patel R, Ishitani MB, Boyce TG (2002) Wound infection with Neisseria weaveri and a novel subspecies of Pasteurella multocida in a child who sustained a tiger bite. Clin Infect Dis 34(12):74-76

Cardall TY, Rosen P (2003) Grizzly bear attack. J Emerg Med 24(3):331333

Chapenoire S, Camiade B, Legros M (2001) Basic instinct in a feline. Am J Forensic Med Pathol 22(1):46-50

Cheney DL, Wrangham RW (1987) Predation. In: Smuts BB, Cheney DL, Seyfarth RM, Wrangham RW, Struhsaker TT (eds) Primate societies. Chic Univ Press, Chic, pp 227-239

Chum M, Pui W (2011) Traumatic tiger attack. J Neurosurg Pediatr 8: 530-534

Cohle SD, Harlan CW, Harlan G (1990) Fatal big cat attacks. Am J Forensic Med Pathol 11(3):208-212

Conrad L (1992) Cougar attack: case report of a fatality. J Wild Med 3: 387-396

Conover MR (2008) Why are so many people attacked by predators? Hum-Wild Confl 2:139-140

Curnoe D, Brink J (2010) Evidence of pathological conditions in the Florisbad cranium. J Hum Evol 50:504-513

Dhar SA, Butt MF, Farooq M, Mir MR, Wani ZA, Afzal S, Sultan A, Wani MI (2008) Pattern of orthopaedic injuries in bear attacks: Report from a tertiary care centre in Kashmir. Injury 39(2):249-255

Delaney-Rivera C, Plummer TW, Hodgson JA, Forrest F, Hertel F, Oliver JS (2009) Pits and pitfalls: taxonomic variability and patterning in tooth mark dimensions. J Archaeol Sci 36(11):2597-2608

Domínguez-Rodrigo M, Piqueras A (2003) The use of tooth pits to identify carnivore taxa in tooth-marked archaeofaunas and their relevance to reconstruct hominid carcass processing behaviours. J Archaeol Sci 30:1385-1391

Dusseldorp GL (2011) Studying Pleistocene Neanderthal and cave hyena dietary habits: combining isotopic and archaeozoological analyses. J Archaeol Method Theory 18:224-255 
Emami P, Kaiser TM, Regelsberger J, Goebell E, Fiehler J, Westphal M, Heese O (2012) Case report: surviving a tiger attack. Neurosurg Rev 35(4):621-624

Estévez J (2004) Vanishing carnivores: What can the disappearance of large carnivores tell us about the Neanderthal world? Int J Osteoarchaeol 14:190-200

Eppinger M, Baar C, Linz B, Raddatz G, Lan C, Keller H, Morelli G, Gressmann H, Achtman M, Schuster S (2006) Who ate whom? Adaptive Helicobacter genomic changes that accompanied a host jump from Early Humans to large felines. PLoS Genet 2(7):10971110

Fay JM, Carroll R, Peterhans JCK, Harris D (1995) Leopard attack on and consumption of gorillas in the Central African Republic. J Hum Evol 29(1):93-99

Fonseca GM, Palacios R (2013) An unusual case of predation: Dog pack or cougar attack? J Forensic Sci 58(1):224-227

Fouriel L, Cartilidge D (1995) Fracture of the maxilla following dog bite to the face. Injury 26(1):61-62

French SP (2001) Bear attacks. In: Auerbach PS (ed) Wilderness Medicine. Mosby, St Louis, pp 974-981

Gade DW (2006) Hyenas and humans in the horn of Africa. Geogr Rev 96(4):609-632

Gamble C (1993) Timewalkers: prehistory of global colonization. Alan Sutton, Stroud

Germonpré M, Sablin MV, Després V, Hofreiter M, Láznicková-Galetová M, Stevens ME, Stiller M (2013) Palaeolithic dogs and the early domestication of the wolf: a reply to the comments of Crockford and Kuzmin (2012). J Archaeol Sci 40:786-792

Gusset M, Swarner MJ, Mponwane L, Keletile K, McNutt JW (2009) Human-wildlife conflict in northern Botswana: livestock predation by Endangered African wild dog Lycaon pictus and other carnivores. Oryx 43(1):67-72

Hart D, Sussman RW (2011) The influence of predation on primate and early human evolution: Impetus for cooperation. In: Sussman RW, Cloninger CR (ed) Origins of altruism and cooperation. Springer, New York, p 19-40

Hayward MW (2006) Prey preferences of the spotted hyaena (Crocuta crocuta) and degree of dietary overlap with the lion (Panthera leo). J Zool 270:606-614

Hazzah L, Mulder MB, Frank L (2009) Lions and warriors: social factors underlying declining African lion populations and the effect of incentive-based management in Kenya. Biol Conserv 142:24282437

Hejna P (2010) A fatal leopard attack. J Forensic Sci 55(3):832-834

Herrero S (1985) Bear attack: their causes and avoidance. N Lyons Books, New York

Herrero S, Fleck S (1990) Injury to people inflicted by black, grizzly or polar bears: recent trends and new insights. Bears: Their Biology and Management, Eighth International Conference on Bear Research and Management. p 25-32

Herrero S, Higgins A (2003) Human injuries inflicted by bears in Alberta: 1960-98. Ursus 14(1):44-54

Horwitz LK, Smith P (1988) The effects of striped hyaena activity on human remains. J Archaeol Sci 15:471-4811

Hussain S (2003) The status of snow leopard in Pakistan and its conflict with local farmer livelihoods. Oryx 37:33-37

Inskip C, Zimmermann A (2009) Human-felid conflict: a review of patterns and priorities worldwide. Oryx 43:18-34

Isotalo PA, Edgar D, Toye B (2000) Polymicrobial tenosynovitis with Pasteurella multocida and other Gram negative bacilli after a Siberian tiger bite. J Clin Pathol 53:871-872

Kiuchi T, Matoba K, Terazawa K (2008) Unusual injuries on the right hand and forearm caused by unidentified wild animals. Leg Med 10: 301-305

Kizer KW (1989) Pasteurella multocida infection from a cougar bite. A review of cougar attacks. West J Med 150(1):87-90
Kneafsey B, Condon KC (1995) Severe dog-bite injuries, introducing the concept of pack attack: a literature review and seven case reports. Injury 26:37-41

Kolowski JM, Holekamp KE (2006) Spatial, temporal and physical characterstics of livestock depredation by large carnivores along a Kenyan reserve border. Biol Conserv 128:529-541

Kunimoto D, Rennie R, Citron DM, Goldstein EJC (2004) Bacteriology of a bear bite wound to a human: case report. J Clin Microbiol 42(7): 3374-3376

Kushnira H, Leitnerb H, Ikandac D, Packerd C (2010) Human and ecological risk factors for unprovoked lion attacks on humans in Southeastern Tanzania. Hum Dimens Wildl Int J 15(5):315-331

Langley RL (2005) Animal-related fatalities in the United States-an update. Wild Environ Med 16:67-74

Langley RL, Hunter JL (2001) Occupational fatalities due to animalrelated events. Wild Environ Med 12:168-174

Lathrop SL (2007) Animal-caused fatalities in New Mexico, 1993-2004. Wild Environ Med 18:288-292

Lauridson JR, Myers L (1993) Evaluation of fatal dog bites: the view of the medical examiner and animal behaviorist. J Forensic Sci 38(3): 726-731

Lehtinen VA, Kaukonen T, Ikäheimo I, Mähönen SM, Koskela M, Ylipalosaari P (2005) Mycobacterium fortuitum infection after a Brown Bear Bite. J Clin Microbiol 43(2):1009

Linnell JDC, Andersen R, Andersone Ž, Balčiauskas L, Blanco JC, Boitani L, Brainerd S, Breitenmoser U, Kojola I, Liberg O, Løe J, Okarma H, Pedersen HC, Promberger C, Sand H, Solberg EJ, Valdmann H, Wabakken P (2002) The fear of wolves: a review of wolf attacks on humans. NorskInstitutt of Naturforskning, Trondheim

MacBean CE, Taylor D, Ashby K (2007) Animal and human bite injuries in Victoria, 1998-2004. Med J Aust 186(1):38-40

Mazzolli M, Graipel ME, Dunstone N (2002) Mountain lion depredation in southern Brazil. Biol Conserv 105:43-51

McKee D (2003) Cougar attacks on humans: a case report. Wild Environ Med 14:169-173

Mitchell KB, Kotecha VR, Chandika A (2011) Bush animal attacks: management of complex injuries in a resource-limited setting. World J Emerg Surg 6:43

Mishra C (1997) Livestock depredation by large carnivores in the Indian Trans Himalaya: conflict perceptions and conservation prospects. Environ Conserv 24:338-343

de Munnynck K, van de Voorde W (2002) Forensic approach of fatal dog attacks: a case report and literature review. Int J Leg Med 116:295300

Murad TA, Boddy MA (1987) A case with bear facts. J Forensic Sci 32(6):1819-1826

Murmann DC, Brumit PC, Schrader BA, Senn DR (2006) A comparison of animal jaws and bite mark patterns. J Forensic Sci 51(4):846-860

Murphy IG, Dempsey MP, Kneafsey B (2007) Tiger bite in captivity. Eur J Plast Surg 30(1):39-40

Musiani MC, Mamo C, Boitani L, Challaghan C, Gates C, Mattei L, Visalberghi E, Breck S, Volpi G (2003) Wolf depredation trends and the use of fladry barriers to protect livestock in western North America. Conserv Biol 17(6):1538-1547

Mussi M (2001) Humans, carnivores and caves in the Italian Middle Paleolithic record. In: Conard NJ (ed) Settlement dynamics of the Middle Palaeolithic and Middles Stone Age. Tübingen Publications in Prehistory, pp 507-518

Nabi DG, Tak SR, Kangoo KA, Halwai MA (2009a) Increasing incidence of injuries and fatalities inflicted by wild animals in Kashmir. Injury 40(1):87-89

Nabi DG, Tak SR, Kangoo KA, Halwai MA (2009b) Injuries from leopard attacks in Kashmir. Injury 40(1):90-92 
Neto MFC, Neto DG, Vidal HV (2011) Attacks by jaguars (Panthera onca) on humans in Central Brazil: report of three cases, with observation of a death. Wild Environ Med 22(2):130-135

Nyhus PJ, Tilson R (2004) Characterizing human-tiger conflict in Sumatra, Indonesia: implications for conservation. Oryx 38(1):6874

Packer C, Ikanda D, Kissui B, Kushnir H (2005) Conservation biology: lion attacks on humans in Tanzania. Nature 436:927-928

Papadopoulos MC, Tubridy N, Wren D, Johnston FG (1999) Neurological symptoms 27 years after tiger bite. J R Soc Med 92: 303-304

Patterson BD, Kasiki SM, Selempo E, Kays RW (2004) Livestock predation by lions (Panthera leo) and other carnivores on ranchers neighboring Tsavo National Park, Kenya. Biol Conserv 119:507-516

Pérez Ripoll M, Morales JV, Sanchis A, Aura Tortosa E, Sarrión I (2010) Presence of the genus Cuon in upper Pleistocene and initial Holocene sites of the Iberian Peninsula: new remains identified in archaeological contexts of the Mediterranean region. J Archaeol Sci 37(3):437-450

Pettigrew M, Xie Y, Kang A, Rao M, Goodrich J, Liu T, Berger J (2012) Human-carnivore conflict in China: a review of current approaches with recommendations for improved management. Integr Zool 7(2): 210-226

Pettitt P (1997) High Resolution Neanderthals? Interpreting Middle Palaeolithic Intrasite Spatial Data. World Archaeol 29(2):208-224

Polisar J, Maxit I, Scognamillo D, Farrell L, Sunquist ME, Eisenburg JF (2003) Jaguars, pumas, their prey base and cattle ranching: ecological interpretations of a management problem. Biol Conserv 109(2):297-310

Prayson MJ, Venkatarayappa I, Srivastava M, Northern I, Burdette SD (2008) Deep infection with Mycoplasma arginini in an open femur fracture secondary to an African lion bite: A case report. Inj Extra 39(7):243-246

Rajpurohit KS, Krausman PR (2000) Human-sloth bear conflicts in Madhya Pradesh, India. Wildl Soc Bull 28:393-399

Rasool A, Wani AH, Darzi MA, Zaroo MI, Iqbal S, Bashir SA, Rashid S, Lone RA (2010) Incidence and pattern of bear maul injuries in Kashmir. Injury 41(1):116-119

Rollins CE, Spencer DE (1995) A fatality and the American mountain lion: bite mark analysis and profile of the offending lion. J Forensic Sci 40(3):486-489

Rosell J, Baquedano E, Blasco R, Camarós E (2012) New insights on Hominid-Carnivore interactions during the Pleistocene. J Taphon 34(10):125-128

Santoro V, Smaldone G, Lozito P, Smaldone M, Introna F (2011) A forensic approach to fatal dog attacks. A case study and review of the literature. Forensic Sci Int 206(1-3):37-42

Schuette P, Wagner AP, Wagner ME, Creel S (2013) Occupancy patterns and niche partitioning within a diverse carnivore community exposed to anthropogenic pressures. Biol Conserv 158:301-312

Sekhar NU (1998) Crop and livestock depredation caused by wild animals in protected areas: the case of Sariska Tiger reserve Rajasthan, India. Environ Conserv 25:160-171
Skuja M (2002) Human-lion conflict around Tarangire National Park, Tanzania. MSc Thesis, Univ of Wisconsin-Madison, Dep Geogr

Stiner MC (1994) Honor among thieves: a zooarchaeological study of Neanderthal ecology. PrincetUniv Press, Princet

Straus LG (1982) Carnivores and cave sites in Cantabrian Spain. J Anthropol Res 38:75-96

Straus LG (1992) Iberia before the Iberians. The Stone Age Prehistory of Cantabrian Spain. Universty New Mexico Press, Albuquerque

Swenson JE, Sandegre F, Soderberg A, Heim M, Sørensen OJ, Bjarvall A, Franzen R, Wikan S, Wabakken P (1999) Interactions between brown bears and humans in Scandinavia. Biosphere Conserv 2:1-9

Thakur JS, Mohan C, Sharma DR (2007) Himalayan black bear mauling: offense or defense? Am J Otolaryngol-Head Neck Med Surg 28: $247-250$

Tillet T (2002) Les grottes à ours et occupations néandertaliennes dans l'arc alpin et jurassien. In: Tillet T, Binford LR (eds) L'Ours et l'Homme. Actes du Colloque d'Auberives-en-Royans. Eraul, Liège, pp 167-184

Treves A, Karanth KU (2003) Human-carnivore conflict and perspectives on carnivore management worldwide. Conserv Biol 17:1491-1499

Treves A, Naughton-Treves L (1999) Risk and opportunity for humans coexisting with large carnivores. J Hum Evol 36:275-282

Trinkaus E (2012) Neandertals, early modern humans, and rodeo riders. J Archaeol Sci 39(12):3691-3693

Türkmen S, Sahin A, Gunaydın M, Tatli O, Karaca Y, Turedi S, Gunduz A (2012) A wild wolf attack and its unfortunate outcome: rabies and death. Wild Environ Med 23(3):248-250

Villaverde V, Martínez Valle R, Guillem P, Fumanal M (1996) Mobility and the role of small game in the Middle Paleolithic of the central region of the Spanish Mediterranean: a comparison of CovaNegra with other Paleolithic deposits. In: Carbonell E, Vaquero M (eds) The last neandertals, the first anatomically modern humans: a tale about the human diversity. Univer Rovira i Virgili, Tarrag, pp 267288

Villaverde V, Guillem PM, Martínez-Valle R, Eixea A (2014) Cova Negra. In: Sala R (ed) Pleistocene and Holocene Hunter-Gatherers in Iberia and the Gibraltar Strait. The current archaeological record. Univ Burgos \& Fund Atapuerca, pp 361-369

Watts HE, Holekamp KE (2007) Hyena societies. Curr Biol 17(16):57-60

Weiss HB, Friedman DI, Coben JH (1998) Incidence of dog bite injuries treated in emergency departments. JAMA 279(1):51-53

Wright JC (1990) Reported cat bites in Dallas: characteristics of the cats, the victims, and the attack events. Public Health Rep 105(4):420 424

Wright JC (1991) Canine aggression toward people. Bite scenarios and prevention. Veterinary Clinics of North America. Small Anim Pract 21(2):299-314

Yirga G, Ersino W, De Iongh HH, Leirs H, Gebrehiwot K, Deckers J, Bauer H (2012) Spotted hyena (Crocuta crocuta) coexisting at high density with people in Wukro district, northern Ethiopia. Mamm Biol 78(3):193-197 